\title{
Dye-sensitised Photocatalyst for Photocatalytic Whole Water Splitting to Produce Hydrogen in a Twin Photoreactor
}

\author{
Yi-Shan Huang ${ }^{1}$, Chao-Wei Huang ${ }^{2}$, Van-Huy Nguyen ${ }^{3}$, Yen-Han Wang ${ }^{1}$, \\ Jeffrey C. S. $\mathrm{Wu}^{1 *}$, Mei-Rurng Tseng ${ }^{4}, \mathrm{Yu}-\mathrm{Chieh} \mathrm{Pao}^{4}$ \\ ${ }^{1}$ Department of Chemical Engineering, National Taiwan University, Taipei, \\ Taiwan 10617 \\ ${ }^{2}$ Department of Chemical and Materials Engineering, National Kaohsiung \\ University of Science and Technology, Kaohsiung, Taiwan 80778 \\ ${ }^{3}$ Faculty of Biotechnology, Binh Duong University, Thu Dau Mot, Vietnam \\ ${ }^{4}$ Material and Chemical Research Laboratories, Industrial Technology Research \\ Institute, Hsinchu, Taiwan 31040 \\ "Corresponding author: cswu@ntu.edu.tw
}

Published online: 15 December 2021

To cite this article: Yi-Shan Huang, Chao-Wei Huang, Van-Huy Nguyen, Yen-Han Wang, Jeffrey C. S. Wu, Mei-Rurng Tseng and Yu-Chieh Pao (2021). Dye-sensitised photocatalyst for photocatalytic whole water splitting to produce hydrogen in a twin photoreactor. Journal of Engineering Science, 17(2), 47-72, https://doi.org/10.21315/ jes2021.17.2.4.

Link to article: https://doi.org/10.21315/jes2021.17.2.4

\begin{abstract}
Organic dye-sensitised $\mathrm{SrTiO}_{3}: \mathrm{Rh}$ and $\mathrm{WO}_{3}$ were served as $\mathrm{H}_{2}$ catalysts and $\mathrm{O}_{2}$ catalysts in a Z-scheme system to conduct photocatalytic pure water splitting. To enhance the light absorption capacity, the composites of organic dye (N3, N719, Z907, black dye, C101, and K19) and $\mathrm{SrTiO}_{3}:$ Rh were synthesised via physical adsorption and then verified by the performance of photocatalytic hydrogen evolution. Among these dyes, $\mathrm{N3}_{-} \mathrm{SrTiO}$ : Rh revealed visible light absorption and exhibited the best photocatalytic activity. Therefore, $N 3$ dye was adopted, and silane coupling agents were used to form chemical bonding with $\mathrm{SrTiO}_{3}: \mathrm{Rh}$. Furthermore, the photocatalytic pure water splitting of $\mathrm{N} 3-\mathrm{SrTiO}$ : $\mathrm{Rh}$ was investigated in a single reactor, and a twin photoreactor with $\mathrm{Fe}^{2+}$ and $\mathrm{Fe}^{3+}$ ions served as the electron mediators, respectively. The highest quantum efficiency can reach $0.0259 \%$ in a twin reactor when compared with the single reactor $(0.0052 \%)$ because of the improvement in the light absorption from N3 and inhibition of the backward reaction of water splitting. Consequently, organic dye-sensitised photocatalysts are highly effective and eco-friendly in conducting photocatalytic pure water splitting.
\end{abstract}

Keywords: organic dye-sensitised photocatalysts, photocatalysis, pure water splitting, hydrogen, simulated sunlight

(C) Penerbit Universiti Sains Malaysia, 2021. This work is licensed under the terms of the Creative Commons Attribution (CC BY) (http://creativecommons.org/licenses/by/4.0/). 


\section{INTRODUCTION}

In recent years, the worldwide use of fossil fuels has led to the depletion of oil resources, triggering energy crises and even international disputes over oil sources. In addition, the burning of oil and natural gas also produces a large amount of carbon dioxide, which exacerbates the greenhouse effect. To solve this problem, hydrogen has become an emerging energy source with great potential for development because of its cleanliness and reusability. Additionally, hydrogen has an extremely high calorific value: up to three times as much as gasoline.

Hydrogen can be produced by using many methods, such as steam reforming reaction (SRR) ${ }^{1}$ and electrolytic water fractionation (EWS). ${ }^{2}$ Steam reforming of hydrocarbons with water vapor can also generate hydrogen and carbon monoxide by using Ni catalysts. Although a large amount of hydrogen is generated from the steam reforming of methane or methanol, it consumes a lot of heat and leads to high $\mathrm{CO}_{2}$ emissions. ${ }^{3}$ On the other hand, the electrolytic reaction of water is a simple procedure: in a water electrolyser device, a bias voltage is applied to both sides of the electrode, and the water molecules at the cathode are reduced to produce hydrogen, while the water molecules at the anode are oxidised to produce oxygen. However, the above-mentioned methods would produce unfavourable gas emissions or consume a lot of energy to generate hydrogen. Therefore, it is crucial to find other promising methods for hydrogen generation, such as photocatalytic and photoelectrochemical water splitting. In 1972, Fujishima and $\mathrm{Honda}^{4}$ showed that a $\mathrm{TiO}_{2}$ semiconductor electrode can decompose water into hydrogen and oxygen under light irradiation. After that, diverse semiconductor materials and reactor designs for photocatalytic hydrogen production have been developed. ${ }^{5-7}$ For a semiconductor material, the positions of the valence band (VB) and conduction band (CB) play a crucial role in photocatalytic water splitting. According to the relative energy levels of semiconductors, the VB should be lower than the oxidation potential of water $\left(\mathrm{E}\left(\mathrm{O}_{2} / \mathrm{H}_{2} \mathrm{O}\right)=1.23 \mathrm{~V}\right.$ at $\left.\mathrm{pH}=0\right)$, and the $\mathrm{CB}$ should be higher than the reduction potential of water $\left(\mathrm{E}\left(\mathrm{H}^{+} / \mathrm{H}_{2}\right)=0 \mathrm{~V}\right.$ at $\mathrm{pH}=0$ ). However, most photocatalysts, such as titanium dioxide, can only absorb ultraviolet light because of their large bandgaps. This means that it can only use about $4 \%$ of solar light to generate photo-excited electron-and-hole pairs. Thus, to enhance the performance of photocatalysis, photocatalysts that can absorb visible light and efficiently perform photocatalytic water splitting reactions have become a major challenge in energy technology. ${ }^{8}$

For improving solar light absorption, most of the literature has focused on the modification of photocatalysts, such as doping, ${ }^{9,10}$ and loading. ${ }^{11,12}$ Doping external atoms into inorganic photocatalysts can increase light absorption in the 
visible light band while loading precious metals on photocatalysts to facilitate the separation and migration of light-induced charge carriers. Nevertheless, solar light is still limited by the bandgap of photocatalysts, which cannot fully absorb visible light. Fortunately, this can be overcome by using a Z-scheme reaction system, which comprises $\mathrm{H}_{2}$ photocatalysts, $\mathrm{O}_{2}$ photocatalysts, and ion mediators. The $\mathrm{CB}$ of $\mathrm{H}_{2}$ photocatalysts needs to meet the demand of being higher than the energy level of water reduction to produce hydrogen. Simultaneously, the VB of $\mathrm{O}_{2}$ photocatalysts needs to meet the demand of being lower than the energy level of water oxidation to produce oxygen. The ion mediators can deliver the holes from the VB of $\mathrm{H}_{2}$ photocatalysts and the electrons from the $\mathrm{CB}$ of $\mathrm{O}_{2}$ photocatalysts to create a balancing neutrality. Therefore, the bandgaps of these two types of photocatalysts can be narrowed down to absorb visible light individually, implying that more diverse semiconductor materials can be employed in photocatalytic water splitting. ${ }^{13}$

Additionally, suppose dye can be physically adsorbed or chemically bonded to a photocatalyst; this can increase the light absorption range of the photocatalyst and improve its photocatalytic ability, a process known as dye sensitisation. When the dye molecules absorb visible light, followed by the stimulation of electrons, the electrons can be transferred to the $\mathrm{CB}$ of photocatalysts to carry out the water reduction and produce hydrogen on the surface. ${ }^{14}$ In 1979, Kiwi and Grätzel first reported that tris(bipyridine)ruthenium(II) $\left[\mathrm{Ru}(\mathrm{bpy})_{3}\right]^{2+}$ and methylviologen $\left(\mathrm{MV}^{+}\right)$were employed as light absorbers and redox mediators, respectively, to sensitise colloidal Platinum catalysts for hydrogen evolution under visible light irradiation. ${ }^{15}$ Since Grätzel's report, dye-sensitised photocatalysis to produce hydrogen has gained a large amount of attention; this was investigated extensively.

Generally, dyes are adopted as sensitisers to donate photo-induced electrons into inorganic metal oxides, which is the only response when it comes to delivering electrons and conducting the surficial hydrogen evolution reaction over photocatalysts. Maeda et al. tried three kinds of $\mathrm{Ru}(\mathrm{III})$ complexes to sensitise metal oxide sheets for photocatalytic hydrogen production in an ethylenediaminetetraacetic acid (EDTA) solution under visible light irradiation. The hydrogen production performance could be increased by the refinement of the tuneable $\mathrm{CB}$ of metal oxides and the excited state of $\mathrm{Ru}(\mathrm{III})$ complexes. ${ }^{16} \mathrm{Yu}$ et al. used N-annulated perylene-based organic dye to sensitise graphitic carbon nitride $\left(\mathrm{g}_{-} \mathrm{C}_{3} \mathrm{~N}_{4}\right)$; they elaborated that the electron transfer and separation between the interface could be improved significantly because of the amide bonds, leading to the better performance of photocatalytic hydrogen production, here reaching $11855.4 \mu \mathrm{mol} \mathrm{h}^{-1} \mathrm{~g}^{-1}{ }^{17}$ Moreover, organic dyes and inorganic metal oxides can be designed to absorb visible light and 
UV light, respectively. Wang et al. ${ }^{18}$ synthesised Eosin Y-sensitised $\mathrm{g}^{-} \mathrm{C}_{3} \mathrm{~N}_{4} /$ $\mathrm{Pt} / \mathrm{GO}$ photocatalysts. Originally, the absorption band edge of $\mathrm{g}_{-} \mathrm{C}_{3} \mathrm{~N}_{4}$ was $\sim 460 \mathrm{~nm}$. After the sensitisation by Eosin Y dye, the visible light absorption was enhanced significantly, thus improving the efficiency of its hydrogen production in $20 \mathrm{vol} \%$ triethanolamine (TEOA) solution; their highest hydrogen production rate was up to $3.82 \mathrm{mmol} \mathrm{h}^{-1} \mathrm{~g}^{-1} .^{18}$

Recently, various composite dye-sensitised photocatalysts have been developed for hydrogen production, for example, dye-sensitised $\mathrm{C}_{3} \mathrm{~N}_{4},{ }^{19,20}$ $\mathrm{TiO}_{2},{ }^{21,22} \mathrm{BiTaO}_{4},{ }^{23} \mathrm{UiO}-66$ metal-organic framework, $,{ }^{24,25} \mathrm{MoS}_{2},{ }^{26}$ and perovskite titanate. ${ }^{27,28}$ Among the various kinds of inorganic metal oxides, perovskites have been comprehensively investigated because they have good photocatalytic activity and high chemical and thermal stability. ${ }^{27}$ However, their wide bandgaps limit the application realised only under UV light radiation. For improving the photocatalytic activity under visible light, which is the largest part (42\%) of the solar spectrum, dye sensitisation ${ }^{27,28}$ and doping technology $y^{9,29}$ have been adopted to enhance visible light absorption. For instance, Chen et al. doped carbon into $\mathrm{KTaO}_{3},{ }^{17}$ Mao et al. modified perovskite $\mathrm{LaNiO}_{3}$ by using $\mathrm{MoS}_{2}$ sensitisation, ${ }^{30}$ and Puangpetch et al. placed Eosin Y dye onto perovskite titanate ${ }^{27}$ to enhance photocatalytic hydrogen production. Nonetheless, using dye-sensitised perovskite photocatalysts is still challenging because of some problems, such as low visible light absorption, the backward reaction of hydrogen and oxygen, and the low electron transfer efficiency between organic dyes and inorganic metal oxides. Therefore, in the current study, various $\mathrm{H}_{2}$ photocatalysts composed of inorganic photocatalysts sensitised by different organic dyes were employed. In addition, N3 dyes were attached or grafted onto perovskite metal oxides through a process of physical adsorption or chemical bonding to verify their effect on the performance of photocatalytic water splitting.

\section{MATERIALS AND METHODS}

\subsection{Photocatalyst Preparation}

The inorganic metal oxide $\mathrm{SrTiO}_{3}: \mathrm{Rh}(1 \%)$ was employed as the photocatalyst for hydrogen production. It was synthesised using the solid-state method at a high temperature, per the guidelines found in the literature. ${ }^{31}$ In our previous study, various calcination temperatures of $\mathrm{SrTiO}_{3}: \mathrm{Rh}$, including $1000^{\circ} \mathrm{C}, 1200^{\circ} \mathrm{C}$, and $1300^{\circ} \mathrm{C}$, were examined, and the results indicate that the calcination temperature would not affect the X-ray diffractometer (XRD) intensity significantly. ${ }^{32}$ However, the UV-Vis spectra of $\mathrm{SrTiO}_{3}: \mathrm{Rh}-1000$ and -1200 were different, leading to an 
apparent difference in hydrogen production. Therefore, the calcination temperatures were further finely tuned from $1000^{\circ} \mathrm{C}, 1100^{\circ} \mathrm{C}$, and $1200^{\circ} \mathrm{C}$ in the current study. First, according to the ratio of stoichiometric ratio of $\mathrm{SrTiO}_{3}: \mathrm{Rh}(1 \%)$, Sr: Ti: Rh $=1:$ 0.99: 0.01 was controlled by weighing the solid precursors, including $\mathrm{SrCO}_{3}$ ( $>99.0 \%$, SHOWA Chemical, Japan), $\mathrm{TiO}_{2}(99.9 \%$, Wako Pure Chemical, Japan), and $\mathrm{Rh}_{2} \mathrm{O}_{3}\left(99.8 \%\right.$, Sigma-Aldrich, USA). Before weighing, $\mathrm{SrCO}_{3}$ was dried in air at $300^{\circ} \mathrm{C}$ for $1 \mathrm{~h}$ to remove the water and impurities. Then, the powders of the three precursors were mixed and ground in a bowl by adding $0.3 \mathrm{~mL}$ of deionised water. To obtain homogeneous powder mixtures, the process of grinding and adding deionised water was repeated three times. The powder mixtures were further placed in an alumina crucible and calcined at different temperatures for $10 \mathrm{~h}$, including $1000^{\circ} \mathrm{C}, 1100^{\circ} \mathrm{C}$, and $1200^{\circ} \mathrm{C}$. The heating rate was $10^{\circ} \mathrm{C} / \mathrm{min}$. After cooling down, the calcined sample was ground in advance to avoid particle agglomeration.

Subsequently, various dyes were employed to be attached onto the photocatalyst, including N3 (cis- bis(isothiocyanato) bis(2,2'- bipyridyl4,4'- dicarboxylato)ruthenium(II), 95\%, UNI-ONWARD, Taiwan), K19 (cis- bis(thiocyanato) (2,2'- bipyridyl- 4,4'- dicarboxylic acid) (4,4'-bis (phexyloxystyryl)-2,2'-bipyridine) ruthenium(II), 95\%, UNI-ONWARD, Taiwan), C101 (cis-Bis (isothiocyanato)(2,2'- bipyridyl- 4,4'- dicarboxylato) (4,4'-bis(5-hexylthiophen-2-yl)-2,2-bipyridyl), ruthenium(II), 95\%, UNIONWARD, Taiwan), N719 (di-tetrabutylammonium cis-bis(isothiocyanato), bis (2,2'-bipyridyl-4,4'-dicarboxylato) ruthenium(II), 95\%, UNI-ONWARD, Taiwan), Z907(cis- Bis(isothiocyanato) (2,2'- bipyridyl- 4,4'-dicarboxylato) (4,4'-dinonyl-2'-bipyridyl) ruthenium(II), 95\%, UNI-ONWARD, Taiwan), and N749 (tris (N,N,N-tributyl-1-butanaminium) [[2,2' '6',2' '-terpyridine]-4,4',4',tricarboxylato(3-)-N1,N1',N1' '] tris(thiocyanato- N) hydrogen ruthenate black dye, 95\%, UNI-ONWARD, Taiwan). First, the selected dye was dissolved in anhydrous ethanol ( $>99.8 \%$, Sigma-Aldrich, USA) to form a dye solution at a concentration of $0.15 \mathrm{M}$. Then $0.1 \mathrm{~g}$ of the calcined $\mathrm{SrTiO}_{3}: \mathrm{Rh}(1 \%)$ was soaked in the dye solution for $24 \mathrm{~h}$. After drying in an oven at $70^{\circ} \mathrm{C}$ for $6 \mathrm{~h}$, the physically adsorbed dye-sensitised photocatalysts were obtained. 


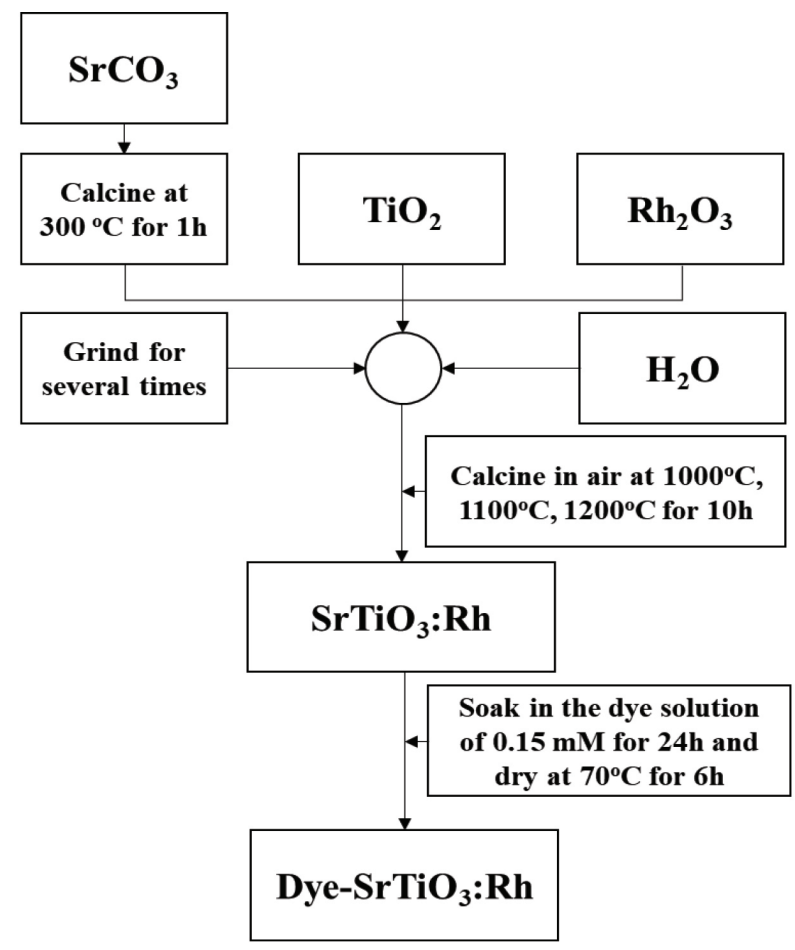

Figure 1: Synthesis of dye-sensitised $\mathrm{SrTiO}_{3}: \mathrm{Rh}$; various dyes, including N3, N719, Z907, black dye, C101, and K19, were employed.

Because N3 dye exhibited the best photocatalytic activity, it was selected for investigating the effect of physical adsorption and chemical bonding for attaching $\mathrm{N} 3$ dyes on $\mathrm{SrTiO}_{3}: \mathrm{Rh}$ photocatalysts. First, the N3 dye was dissolved in an anhydrous ethanol ( $>99.8 \%$, Sigma-Aldrich, USA) at a concentration of $0.15 \mathrm{M}$. Then, $0.1 \mathrm{~g} \mathrm{SrTiO}_{3}: \mathrm{Rh}(1 \%)$, which was calcined at $1100^{\circ} \mathrm{C}$, was soaked in the dye solution for $24 \mathrm{~h}$, followed by drying in an oven at $70^{\circ} \mathrm{C}$ for $\sim 6 \mathrm{~h}$. Then, the physically adsorbed dye-sensitised photocatalysts were obtained. The method for connecting the photocatalyst and the N3 dye by chemical bonding used a coupling agent as a bridge between them. One end of the coupling agent was connected with the hydrophilic group on the surface of the photocatalyst; the other end was connected with the $-\mathrm{NH}_{2}$ group and $\mathrm{COOH}$ groups from the dyes to form a stable chemical bond via dehydration. ${ }^{33}$ However, the amount of hydrophilic groups on the $\mathrm{SrTiO}_{3}: \mathrm{Rh}$ was little. To enhance the $\mathrm{OH}$ groups on the surface of the photocatalysts, surficial modification was conducted by UV and ozone treatment (STARKER UV OZONE IAST0001-015, Grand Hand Instrument Co., Ltd, Taiwan) for $60 \mathrm{~min}$. With the surface treatment, hydrophilic groups on $\mathrm{SrTiO}_{3}: \mathrm{Rh}$, such as $\mathrm{OH}$ groups, were formed and reacted with the coupling 
agent more easily. Initially, $\gamma$-aminopropyltriethoxysilane (APTES, 99.9\%, Sigma-Aldrich, USA) as the coupling agent was added into 95\% ethanol solution with continuous stirring at room temperature for $1 \mathrm{~h}$. Accordingly, the $\mathrm{SrTiO}_{3}$ : $\mathrm{Rh}(1 \%)$ with the surface treatment was added to the solution for $1 \mathrm{~h}$. Then, the mixture was centrifugally filtered to remove the solvent, followed by washing with ethanol and deionised water three times each. Afterward, the samples were dried at $110^{\circ} \mathrm{C}$, and the modified $\mathrm{SrTiO}_{3}: \mathrm{Rh}(1 \%)$ was obtained. Next, the modified photocatalysts, dicyclohexylcarbodiimide (DCC, 99\%, Sigma-Aldrich, USA), 4-dimethylaminopyridine (DMAP, $>99 \%$, Sigma-Aldrich, USA), and N3 dye were mixed in the solvent of tetrahydrofuran with refluxing at $80^{\circ} \mathrm{C}$ for $6 \mathrm{~h}$. Finally, after further filtering and drying, chemically bonded N3-SrTiO ${ }_{3}:$ Rh dye-sensitised photocatalysts were synthesised. The details of the dye-sensitised photocatalysts are summarised in Table 1.

Table 1: Summary of the photocatalysts used in the study.

\begin{tabular}{llll}
\hline Name & Dye & Bonding type & Based photocatalysts \\
\hline $\mathrm{SrTiO}_{3}: \mathrm{Rh}-1000^{\circ} \mathrm{C}$ & none & none & $\mathrm{SrTiO}_{3}: \mathrm{Rh}-1000^{\circ} \mathrm{C}$ \\
$\mathrm{SrTiO}_{3}: \mathrm{Rh}-1100^{\circ} \mathrm{C}$ & none & none & $\mathrm{SrTiO}_{3}: \mathrm{Rh}-1100^{\circ} \mathrm{C}$ \\
$\mathrm{SrTiO}_{3}: \mathrm{Rh}^{\circ} 1200^{\circ} \mathrm{C}$ & none & none & $\mathrm{SrTiO}_{3}: \mathrm{Rh}-1200^{\circ} \mathrm{C}$ \\
$\mathrm{N}_{3}-\mathrm{SrTiO}_{3}: \mathrm{Rh}$ & $\mathrm{N} 3$ & & \\
$\mathrm{~K}_{19}-\mathrm{SrTiO}_{3}: \mathrm{Rh}$ & $\mathrm{K} 19$ & & \\
$\mathrm{C} 101-\mathrm{SrTiO}_{3}: \mathrm{Rh}$ & $\mathrm{C} 101$ & & \\
$\mathrm{~N} 719-\mathrm{SrTiO}_{3}: \mathrm{Rh}$ & $\mathrm{N} 719$ & physically & $\mathrm{SrTiO}_{3}: \mathrm{Rh}-1100^{\circ} \mathrm{C}$ \\
$\mathrm{Z} 907-\mathrm{SrTiO}_{3}: \mathrm{Rh}$ & $\mathrm{Z} 907$ & & \\
$\mathrm{Black} \mathrm{Rye}_{-}-\mathrm{SrTiO}_{3}: \mathrm{Rh}$ & $\mathrm{Black}$ dye & & \\
$\mathrm{N}_{3}-\mathrm{SrTiO}_{3}: \mathrm{Rh}$ & $\mathrm{N} 3$ & chemically & \\
\hline
\end{tabular}

\subsection{Photocatalyst Characterisation}

For inspecting the crystalline structures, the $\mathrm{SrTiO}_{3}: \mathrm{Rh}$ photocatalysts that were prepared at different calcination temperatures were characterised by an XRD using an M03XHF Ultima IV (Rigaku) with $\mathrm{Cu} \mathrm{K} \alpha$ radiation $(\lambda=0.15418 \mathrm{~nm}$ ). The scanning rate was set at $10^{\circ} / \mathrm{min}$, and the $2 \theta$ range was $20 \sim 80^{\circ}$. The UV visible light absorption of the dye solution and diffuse reflectance spectra of the prepared dye-sensitised $\mathrm{SrTiO}_{3}: \mathrm{Rh}$ were examined using a Cary 300 (Varian). The measurement range of UV visible light absorption was $200 \sim 800 \mathrm{~nm}$. The scanning rate was $120 \mathrm{~nm} / \mathrm{min}$. The particle size distribution of the $\mathrm{SrTiO}_{3}: \mathrm{Rh}$ photocatalysts was obtained by dynamic light scattering on the particle size analyser of a Malvern ZetaSizer (Nano-size). The wavelength of the exciting laser source was $633 \mathrm{~nm}$ (red). Before conducting the particle size measurement, 
the samples were suspended in anhydrous ethanol with ultrasonic oscillation for $2 \mathrm{~h}$ to avoid particle agglomeration. The specific surface areas of the $\mathrm{SrTiO}_{3}: \mathrm{Rh}$ photocatalysts were measured according to the $\mathrm{N}_{2}$ adsorption-desorption isotherm curve by Micromeritics ASAP 2010. The degas temperature was $100^{\circ} \mathrm{C}$, and the vacuum pressure was below $5 \mu \mathrm{m} \mathrm{Hg}$. The amount of $\mathrm{H}_{2}$ and $\mathrm{O}_{2}$ generated from the photocatalytic water splitting was measured by GC-TCD (gas chromatography equipped thermal conductivity detector, China Chromatography GC 2000) with a column molecular sieve 5A. The carrier gas was Ar (99.9995\%, Shen Yi Gas, Taiwan).

\subsection{Photocatalytic Water Splitting}

The performance of the photocatalytic water splitting was evaluated via three types of reaction systems: (1) the half-reaction of water splitting (hydrogen evolution) in a single reactor; (2) the whole reaction of water splitting in a single reactor; and (3) the whole reaction of water splitting in a twin reactor. All reactors employed in the current study, including a single reactor or a twin reactor, were made of glass. For the first system, as a sacrificial agent, $2 \mathrm{mM} \mathrm{FeCl}_{2}$ (iron (II) chloride, $99.0 \%$, Sigma-Aldrich, USA) was prepared in $100 \mathrm{~mL}$ deionised water in a single reactor, followed by adjusting the $\mathrm{pH}$ value to 2.4 by adding $\mathrm{H}_{2} \mathrm{SO}_{4}$ (sulfuric acid, 96\%, Sigma-Aldrich, USA). Then, $0.1 \mathrm{~g} \mathrm{SrTiO}_{3}: \mathrm{Rh}$ or dye-sensitised $\mathrm{SrTiO}_{3}: \mathrm{Rh}$ photocatalyst was placed in the prepared solution by applying ultrasonic oscillation for $10 \mathrm{~min}$. Before light irradiation, a single reactor was purged with argon for $5 \mathrm{~min}$ to remove air from the system. To conduct the half-reaction of water splitting, the solution was stirred continuously and irradiated by $300 \mathrm{~W}$ Xe lamp (Newport, Model 66902) with an AM $1.5 \mathrm{G}$ filter for $4 \sim 8 \mathrm{~h}$. Then, the produced hydrogen would be sampled by $0.5 \mathrm{~mL}$ gas syringe each hour and monitored by GC-TCD (CHINA CHROMATOGRAPHY GC 2000, Taiwan) with a column of molecular sieve $5 \mathrm{~A}(\mathrm{MS}-5 \mathrm{~A})$.

For the second system, $1 \mathrm{mM} \mathrm{FeCl}_{2}$ and $1 \mathrm{mM} \mathrm{FeCl}_{3}$ (iron (III) chloride, $97.0 \%$, Sigma-Aldrich, USA) were used as the electron mediator pairs and were added into a single reactor to conduct the whole reaction of water splitting. After adjusting the $\mathrm{pH}$ value to $2.4,0.1 \mathrm{~g}$ of commercial $\mathrm{WO}_{3}$ (tungsten(VI) oxide, $>99.9 \%$, Sigma-Aldrich, USA) and $0.1 \mathrm{~g}$ of the prepared N3-sensitised $\mathrm{SrTiO}_{3}: \mathrm{Rh}$ photocatalysts were dispersed in the solution by stirring. Following the steps of ultrasonic oscillation and argon purging, the system was irradiated by a $300 \mathrm{~W}$ Xe lamp with an AM $1.5 \mathrm{G}$ filter for $8 \mathrm{~h}$. The produced hydrogen and oxygen were inspected by GC-TCD. 
After this, the whole reaction of water splitting in a twin reactor, which was regarded as the third system, was conducted. The twin reactor system was comprised of two cells. One side was to generate hydrogen by adding deionised water, $2 \mathrm{mM}$ $\mathrm{FeCl}_{2}$, and $0.22 \mathrm{~g}$ of the prepared $\mathrm{N} 3$-sensitised $\mathrm{SrTiO}_{3}: \mathrm{Rh}$ photocatalysts. The other side was to generate oxygen by adding deionised water, $2 \mathrm{mM} \mathrm{FeCl}_{3}$, and $0.22 \mathrm{~g}$ of commercial $\mathrm{WO}_{3}$. Two cells were connected by a glass channel, which was fixed with a rubber-made O-ring and a stainless-steel clamper. The $\mathrm{pH}$ values of the solution on both sides were tuned to 2.4. A modified Nafion ion-exchange membrane was also used within the glass channel to separate the photocatalysts in the $\mathrm{H}_{2}$ - and $\mathrm{O}_{2}$-producing sides. In such a twin reactor, $\mathrm{Fe}^{2+}$ and $\mathrm{Fe}^{3+}$ served as the ion mediators, while $\mathrm{H}^{+}$was adopted to balance the chemical potential between the two sides by migration. Then, two cells were irradiated simultaneously by a $300 \mathrm{~W}$ Xe lamp with an AM 1.5G filter for $8 \mathrm{~h}$. The detailed setup of the Z-scheme twin reactor can be found in our previous studies..$^{13,34}$

\section{RESULTS AND DISCUSSION}

\subsection{Characteristics of Photocatalysts}

The XRD analysis of various $\mathrm{SrTiO}_{3}: \mathrm{Rh}$ photocatalysts prepared at different calcination temperatures is shown in Figure 2. The spectra of the $\mathrm{SrTiO}_{3}: \mathrm{Rh}$ photocatalysts had significant peaks at $32.4^{\circ}, 40.0^{\circ}, 46.5^{\circ}, 57.8^{\circ}, 67.8^{\circ}, 72.6^{\circ}$, and $77.2^{\circ}$, which corresponded to the characteristic peaks of $\mathrm{SrTiO}_{3}$ in Joint Committee on Powder Diffraction Standards (JCPDS) (standard card 74-1296). It is interesting to note that there was no characteristic peak of $2 \theta=31^{\circ}$, which would correspond to the peak of $\mathrm{Sr}_{3} \mathrm{Ti}_{2} \mathrm{O}_{7}$. This suggests that the calcination temperature is high enough to form $\mathrm{SrTiO}_{3}$, instead of tetragonal crystal $\mathrm{Sr}_{3} \mathrm{Ti}_{2} \mathrm{O}_{7}$, which appeared only at lower calcination temperature. On the other hand, there was no characteristic peak $\left(2 \theta=27.54^{\circ}\right)$ of $\mathrm{SrCO}_{3}$ observed, indicating that the photocatalysts prepared by the solid-state method could form the $\mathrm{SrTiO}_{3}$ crystal phase without any other residue of the precursors. Additionally, no other additional characteristic peaks were observed, suggesting that $\mathrm{Rh}$ was well incorporated into the structure of $\mathrm{SrTiO}_{3}$ without changing its framework; hence, the prepared $\mathrm{SrTiO}_{3}: \mathrm{Rh}$ showed a good crystallinity. Meanwhile, no appearance of the Rh metal peak indicated that $\mathrm{Rh}$ was doped into $\mathrm{SrTiO}_{3}: \mathrm{Rh}$ successfully or dispersed well onto $\mathrm{SrTiO}_{3}: \mathrm{Rh}$ in the form of fine particles, which were too small in size or content to be detected. A similar phenomenon can be found in the literature. ${ }^{35}$ 


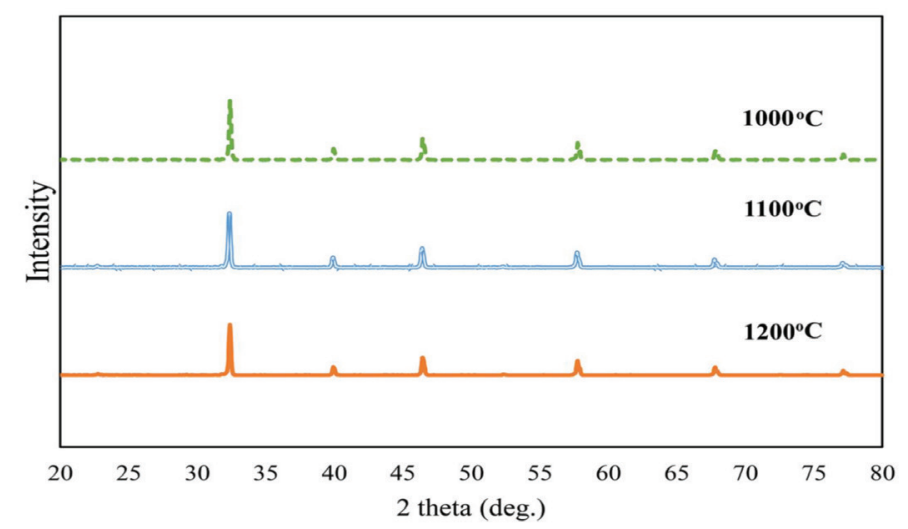

Figure 2: XRD analysis of various $\mathrm{SrTiO}_{3}: \mathrm{Rh}$ photocatalysts prepared at $1000^{\circ} \mathrm{C}, 1100^{\circ} \mathrm{C}$, and $1200^{\circ} \mathrm{C}$.

The UV-Vis light spectra of $\mathrm{SrTiO}_{3}: \mathrm{Rh}$ synthesised at various calcination temperatures are shown in Figure 3. Here, as the calcination temperature increased, the absorption peak around $580 \mathrm{~nm}$ increased, suggesting that $\mathrm{SrTiO}_{3}: \mathrm{Rh}$ photocatalysts prepared at $1200^{\circ} \mathrm{C}$ could absorb more part of the visible light than those at $1000^{\circ} \mathrm{C}$ and $1100^{\circ} \mathrm{C}$. For the visual inspection, the samples prepared at $1200^{\circ} \mathrm{C}$ also showed a dark grey colour more significantly than others, corresponding to the absorption range from 500 to $650 \mathrm{~nm}$ in the UV-Vis spectra. In addition, the bandgap of the prepared samples could be obtained by the Tauc plot so that the bandgap of the $\mathrm{SrTiO}_{3}: \mathrm{Rh}$ photocatalysts prepared at $1000^{\circ} \mathrm{C}, 1100^{\circ} \mathrm{C}$, and $1200^{\circ} \mathrm{C}$ were $2.71 \mathrm{eV}, 2.65 \mathrm{eV}$, and $2.28 \mathrm{eV}$, respectively. Hence, a higher calcination temperature could lower the bandgap of $\mathrm{SrTiO}_{3}: \mathrm{Rh}$ photocatalysts.

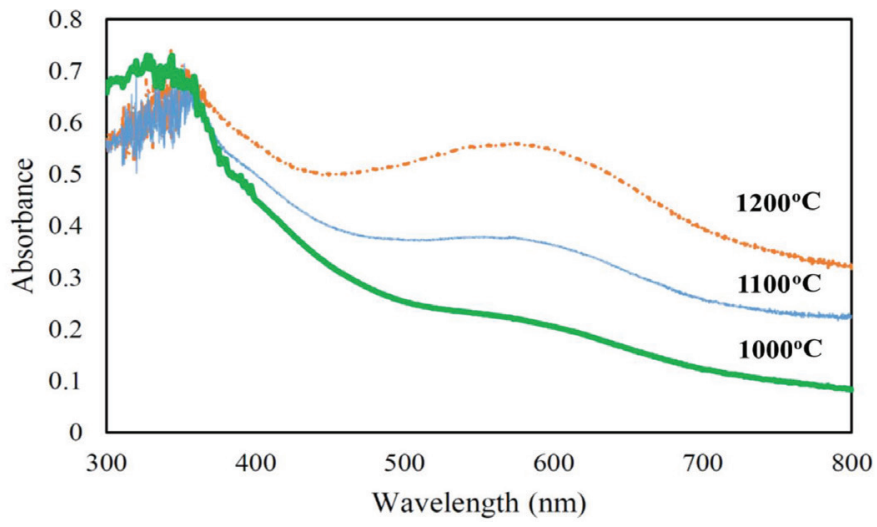

Figure 3: UV-Vis light spectra of various $\mathrm{SrTiO}_{3}: \mathrm{Rh}$ photocatalysts prepared at $1000^{\circ} \mathrm{C}$, $1100^{\circ} \mathrm{C}$, and $1200^{\circ} \mathrm{C}$. 
The UV-Vis light spectra of dye-sensitised $\mathrm{SrTiO}_{3}: \mathrm{Rh}\left(1100^{\circ} \mathrm{C}\right)$ physically adsorbed with different dyes are depicted in Figure 4, indicating that with the addition of various dyes, the absorption of dye-sensitised photocatalysts in the range of visible light was significantly improved. Among the photocatalysts, the visible light absorption of $\mathrm{Z} 907-\mathrm{SrTiO}_{3}: \mathrm{Rh}$, black dye- $\mathrm{SrTiO}_{3}: \mathrm{Rh}$, and $\mathrm{N} 719$ $\mathrm{SrTiO}_{3}: \mathrm{Rh}$ were still low, and $\mathrm{N} 3-\mathrm{SrTiO}_{3}: \mathrm{Rh}$ exhibited the highest absorption. Although the C101 and K19 dyes showed an outstanding absorption of visible light, few C101 and K19 dyes molecules were attached to the C101 and K19 photocatalysts, leading to a lower light absorption than that of $\mathrm{N}_{3}-\mathrm{SrTiO}_{3}: \mathrm{Rh}$. The absorption bands below $350 \mathrm{~nm}$ could be ignored because most of the UV light was absorbed by the glass reactor during photocatalytic water splitting. Therefore, the N3 dye was more suitable for synthesising dye-sensitised photocatalysts for photocatalytic water-splitting reactions.

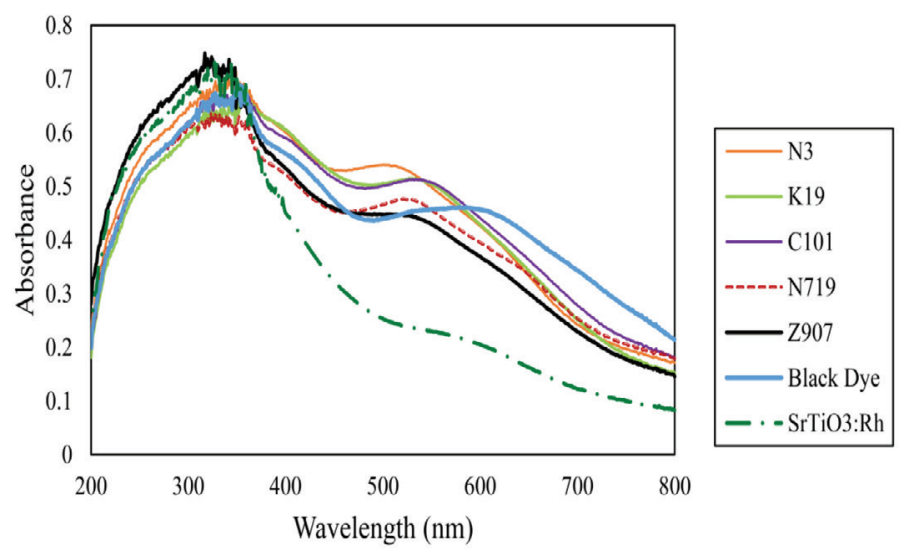

Figure $4 \mathrm{UV}-\mathrm{Vis}$ light spectra of different dye-sensitised $\mathrm{SrTiO}_{3}: \mathrm{Rh} \quad\left(1100^{\circ} \mathrm{C}\right)$ photocatalysts.

By conducting dynamic light scattering measurements, the average diameters of $\mathrm{SrTiO}_{3}: \mathrm{Rh}$ synthesised at $1000^{\circ} \mathrm{C}, 1100^{\circ} \mathrm{C}$, and $1200^{\circ} \mathrm{C}$ were obtained at $559.0 \mathrm{~nm}, 606.6 \mathrm{~nm}$, and $672.6 \mathrm{~nm}$, respectively. Their diameters ranged from approximately 550 to $700 \mathrm{~nm}$, indicating that their particles were uniform and that the particle size distribution was narrow. In addition, according to the results of the $\mathrm{N}_{2}$ adsorption, the specific surface area of $\mathrm{SrTiO}_{3}: \mathrm{Rh}$ synthesised at various calcination temperatures could also be confirmed. The specific surface areas of $\mathrm{SrTiO}_{3}: \mathrm{Rh}$ calcined at $1000^{\circ} \mathrm{C}, 1100^{\circ} \mathrm{C}$, and $1200^{\circ} \mathrm{C}$ were $4.2 \mathrm{~m}^{2} / \mathrm{g}, 3.8 \mathrm{~m}^{2} / \mathrm{g}$, and $3.1 \mathrm{~m}^{2} / \mathrm{g}$, respectively. This indicates that as the calcination temperature increased, the specific surface area of the prepared photocatalysts decreased. Generally, photocatalysts tend to form larger particles under high-temperature calcination to reduce the specific surface area. This result is consistent with that of the particle 
size analysis. Theoretically, $\mathrm{SrTiO}_{3}: \mathrm{Rh}$ calcined at $1000^{\circ} \mathrm{C}$ should have the smallest particle size and the maximum specific surface area, resulting in the best photocatalytic activity; however, its UV-Vis spectrum analysis revealed poor light absorption, which might lead to poor photocatalytic activity. Therefore, the optimal calcination temperature still needed to be tested and validated by conducting a water-splitting reaction.

\subsection{Photocatalysis Performance}

First, a half-reaction of water splitting in a single reactor was conducted. Figure 5 shows the results of the total hydrogen evolution by using various $\mathrm{SrTiO}_{3}: \mathrm{Rh}$ photocatalysts prepared at $1000^{\circ} \mathrm{C}, 1100^{\circ} \mathrm{C}$, and $1200^{\circ} \mathrm{C}$ after $4 \mathrm{~h}$ irradiation of simulated solar light. The $\mathrm{SrTiO}_{3}: \mathrm{Rh}$ photocatalysts calcined at $1100^{\circ} \mathrm{C}$ exhibited the highest hydrogen evolution, followed by $\mathrm{SrTiO}_{3}: \mathrm{Rh}$ at $1200^{\circ} \mathrm{C}$ and $1000^{\circ} \mathrm{C}$. According to the results of the UV-Vis analysis, the light absorption of the photocatalysts in the range of visible light rose with an increase of in the calcination temperature, resulting in a greater possibility of generating light-induced electrons and holes for photocatalytic reactions. Conversely, the increasing calcination temperature showed a negative effect on photocatalytic activity because of the increase in particle size and decrease in specific surface area. When the average particle size increased, the light-induced electrons and holes migrated long distances to the surface, leading to an increased probability of the recombination of electrons and holes and a lower photocatalytic activity. Similar results were also verified in a previous study ${ }^{36}$ If the calcination temperature was too low, it was not easy to form a photocatalyst with good crystallinity. On the contrary, when the calcination temperature was too high, it led to larger particle sizes. Therefore, the $\mathrm{SrTiO}_{3}: \mathrm{Rh}$ photocatalysts prepared at $1100^{\circ} \mathrm{C}$ exhibited the best performance for the half-reaction of photocatalytic water-splitting reaction, and they were employed as the base materials in subsequent experiments. For comparison, a similar investigation using $\mathrm{TiO}_{2}$ was also conducted. There was no hydrogen detected during the whole photocatalytic water-splitting reaction in the presence of $\mathrm{TiO}_{2}$. 


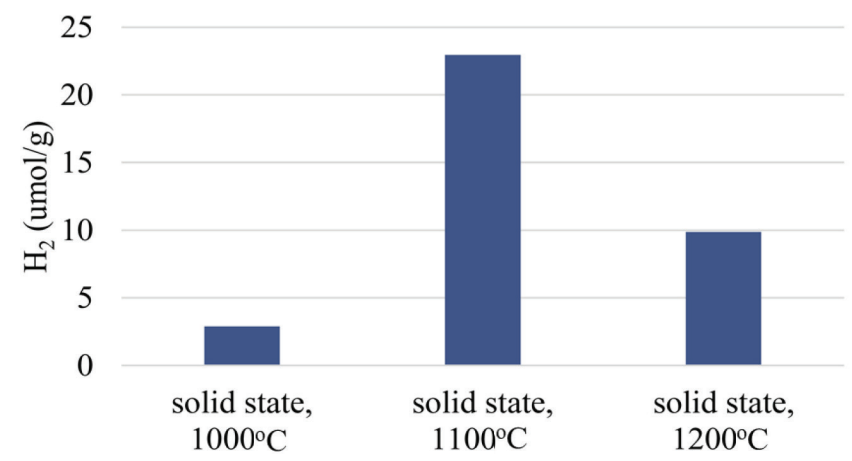

Figure 5: The hydrogen evolution in a half-reaction of photocatalytic water splitting after $4 \mathrm{~h}$ using various $\mathrm{SrTiO}_{3}: \mathrm{Rh}$ photocatalysts prepared at $1000^{\circ} \mathrm{C}, 1100^{\circ} \mathrm{C}$, and $1200^{\circ} \mathrm{C}$.

In advance, the half-reaction over different dye-sensitised $\mathrm{SrTiO}_{3}: \mathrm{Rh}$ $\left(1100^{\circ} \mathrm{C}\right)$ photocatalysts was also conducted. Figure 6 shows the amount of hydrogen evolution over various physically adsorbed photocatalysts after 4 h. Compared with pure $\mathrm{SrTiO}_{3}: \mathrm{Rh}$ photocatalysts, dye-sensitised $\mathrm{SrTiO}_{3}: \mathrm{Rh}$ photocatalysts generated more hydrogen, implying that dye sensitisation could improve the performance of the photocatalytic reaction. In addition, the condition of only a dye solution without adding photocatalysts was also examined. In this case, no hydrogen was generated, suggesting that the dye molecules were not suitable to serve as photocatalysts. Dyes must be attached to the photocatalysts as a light antenna and then absorb visible light to produce excited electrons to conduct the subsequent photocatalytic reaction.

Among the six dye-sensitised photocatalysts, N3-SrTiO $:$ Rh exhibited the best hydrogen evolution performance at approximately $112 \mu \mathrm{mol} / \mathrm{g}$ in $4 \mathrm{~h}$. The performance of the photocatalytic reaction via dye modification followed the order N3, C101, Z907, K19, N719, and black dye. The reasons for these results can be derived from several possible factors, such as the visible light absorption of the dye-sensitised photocatalysts, the position of the VB and $\mathrm{CB}$, and the dye adsorption capacity on the photocatalyst. To sum up, dye N3 was more suitable for photocatalytic water splitting; therefore, it was adopted for conducting further experiments. 


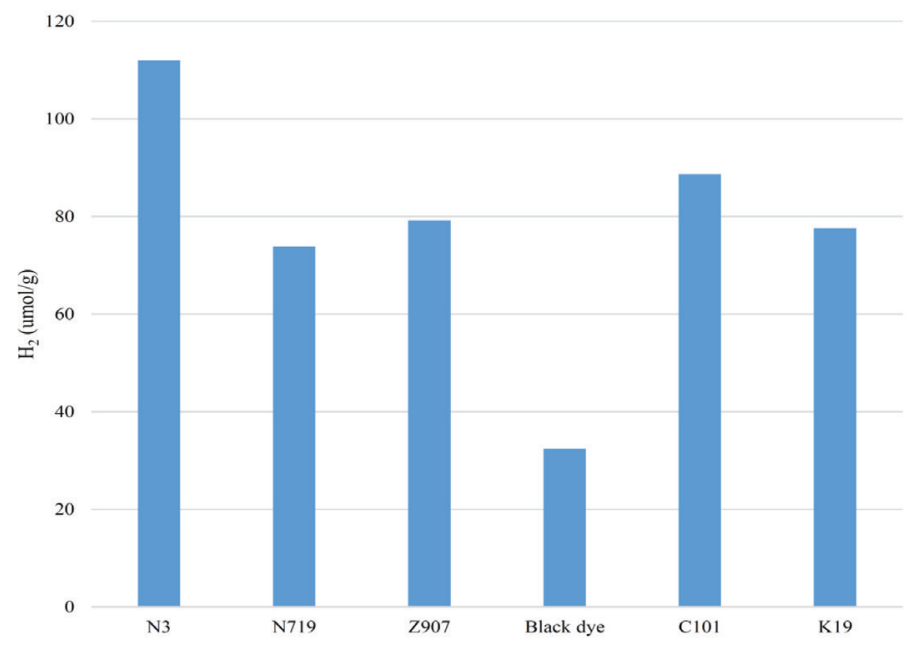

Figure 6: The hydrogen evolution in a half-reaction of photocatalytic water splitting over $4 \mathrm{~h}$ using various dye-sensitised $\mathrm{SrTiO}_{3}: \mathrm{Rh}$ photocatalysts prepared at $1100^{\circ} \mathrm{C}$.

The hydrogen evolution in the half-reaction of water splitting using $\mathrm{N} 3-\mathrm{SrTiO}_{3}: \mathrm{Rh}$ photocatalysts in a single reactor is shown in Figure 7. There is no oxygen measured in this system because of the addition of $\mathrm{Fe}^{2+}$, which plays the role of a sacrificial reagent in capturing the excited holes. The excited holes oxidised $\mathrm{Fe}^{2+}$ into $\mathrm{Fe}^{3+}$ instead of the water oxidation; therefore, hydrogen was stably generated. It was observed that during the first $6 \mathrm{~h}$, there was a rising trend of hydrogen evolution with time. However, the total amount of hydrogen was slightly decreased at $7 \mathrm{~h}$ and rose again at $8 \mathrm{~h}$. After $8 \mathrm{~h}$, no hydrogen was produced, suggesting that the half-reaction was terminated. Finally, the hydrogen evolution could reach $\sim 130 \mu \mathrm{mol} / \mathrm{g}$ in $8 \mathrm{~h}$. We found that the N3 dyes were leached out or desorbed from the physically adsorbed N3-SrTiO3:Rh photocatalysts during the experiment. Afterward, N3 dyes were evenly dispersed in the aqueous solution, and the colour of the solution turned pink. Because the binding between N3 dyes and $\mathrm{SrTiO}_{3}: \mathrm{Rh}$ photocatalysts was not strong enough for physically adsorbed $\mathrm{N} 3-\mathrm{SrTiO}_{3}: \mathrm{Rh}$ photocatalysts, hydrophilic N3 dyes were easily leached into the water. While light irradiating such a reaction system, it became difficult for the excited electrons to be transferred to $\mathrm{SrTiO}_{3}: \mathrm{Rh}$ photocatalysts, resulting in the termination of the photocatalytic water splitting reaction and stagnation of hydrogen generation. 


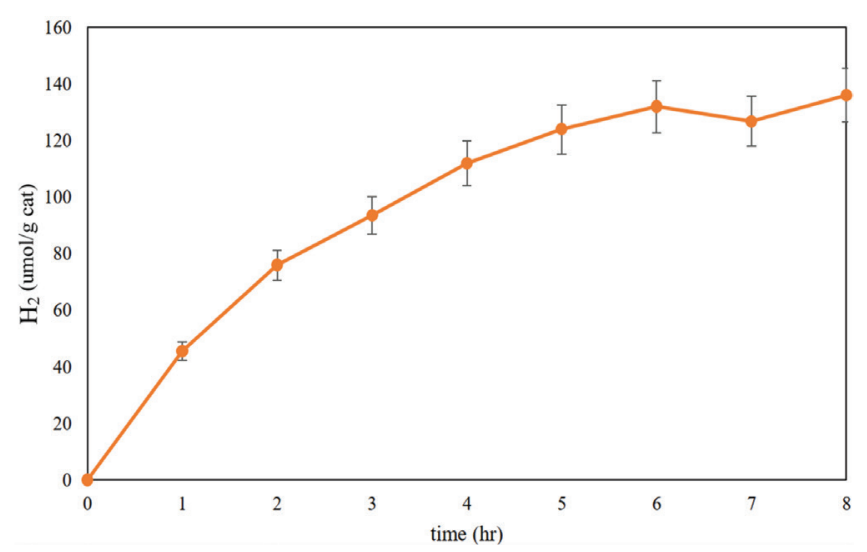

Figure 7: The hydrogen evolution in the half-reaction of water splitting after $8 \mathrm{~h}$ using physically adsorbed $\mathrm{N} 3-\mathrm{SrTiO}_{3}: \mathrm{Rh}$ photocatalysts.

As shown in Figure 8, for the entire reaction of water splitting in a single reactor, the trend of hydrogen production was similar to the result of the halfreaction in a single reactor. In the initial stage of the reaction, hydrogen production increased steadily. However, no hydrogen was produced after 6 h. It was also observed that the colour of the reaction solution gradually became darker pink, similar to the colour of the half-reaction system; this indicates that the physically adsorbed N3 dye would be desorbed from the surface of the $\mathrm{SrTiO}_{3}: \mathrm{Rh}$ photocatalyst and dissolved in water, leading to the cessation of hydrogen generation after $6 \mathrm{~h}$.

Furthermore, comparing the hydrogen production between the whole reaction and half-reaction in a single reactor, the hydrogen production of the whole reaction system was greatly reduced, and only $\sim 15 \mu \mathrm{mol} / \mathrm{g}$ of hydrogen was produced after $4 \mathrm{~h}$. The possible reason for this is that the hydrogen-producing photocatalysts and oxygen-producing photocatalysts were mixed in the same reactor in the whole reaction system. These two photocatalysts might shield each other and cause competition for light source absorption, thereby reducing reaction efficiency. Another reason is that under this whole reaction system, hydrogen and oxygen were generated in the same reactor simultaneously, thus promoting the reverse reaction of hydrogen and oxygen back to the water and resulting in a reduction in hydrogen production. In addition, hydrogen might also be oxidised by $\mathrm{Fe}^{3+}$ ions, and similarly, oxygen might be reduced by $\mathrm{Fe}^{2+}$ ions in water. These possible reverse reactions cause a reduction in hydrogen production. ${ }^{37}$ On the other hand, it could still be found that the ratio of hydrogen to oxygen was approximately $2: 1$, corresponding to the stoichiometric ratio of water. Nevertheless, there was a slight deviation from the expected amount of oxygen, possibly from the air leakage during sampling when using a gastight syringe. 


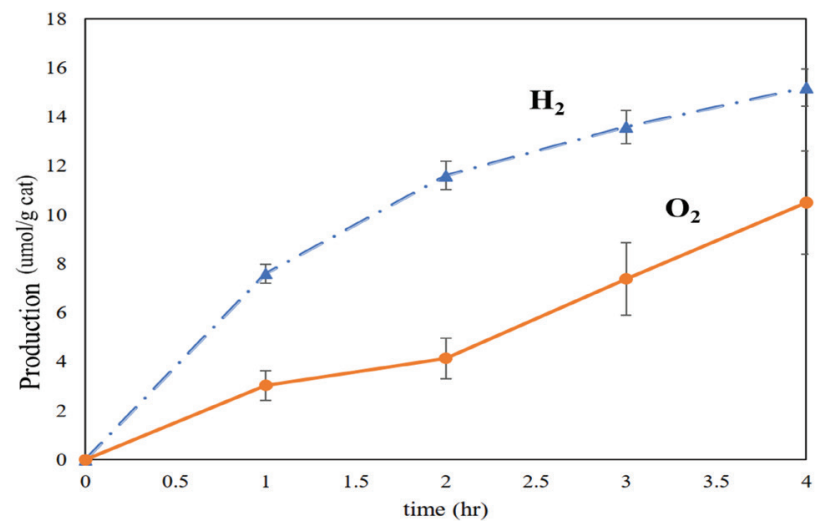

Figure 8: The hydrogen and oxygen production of the whole water-splitting reaction in a single reactor using physically adsorbed $\mathrm{N} 3-\mathrm{SrTiO}_{3}: \mathrm{Rh}$ photocatalysts.

While conducting the whole reaction of water splitting in a single reactor, the competition of light absorption by hydrogen-producing photocatalysts and oxygen-producing photocatalysts could not be avoided. Therefore, using a twin reactor can solve this issue, preventing the occurrence of a reverse reaction, here referring to hydrogen and oxygen in the water. In the twin reactor, oxidation and reduction reactions occurred in the different cells, which were divided by a Nafion exchange membrane. The Nafion membrane allowed the diffusion of protons- $-\mathrm{Fe}^{2+}$ and $\mathrm{Fe}^{3+}$ ions - to pass through and separated $\mathrm{H}_{2}$ and $\mathrm{O}_{2}$ in two cells. Compared with the twin reactor results and that in the single reactor, the hydrogen production increased to $19 \mu \mathrm{mol} / \mathrm{g}$ within $4 \mathrm{~h}$ of light irradiation. The design of the twin reactor substantially improved the reaction efficiency of photocatalytic water splitting. In addition, the stoichiometric ratio of hydrogen and oxygen was close to $2: 1$.

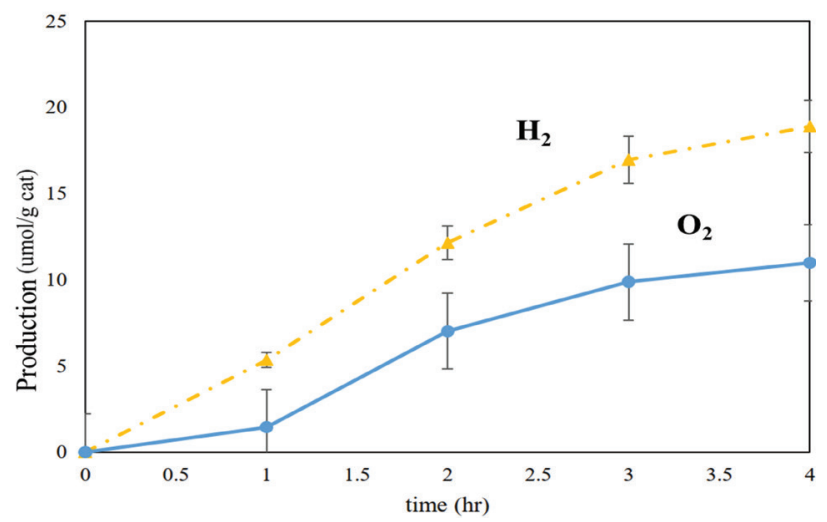

Figure 9: The hydrogen and oxygen production of the whole water-splitting reaction in a twin reactor using physically adsorbed $\mathrm{N} 3-\mathrm{SrTiO}_{3}: \mathrm{Rh}$ photocatalysts. 
Furthermore, the $\mathrm{pH}$ value of the solution in each cell of the twin reactor was adjusted. As shown in Figure 10, the condition of $\mathrm{pH} 1.9$ exhibited the highest hydrogen production of $100 \mu \mathrm{mol} / \mathrm{g}$ within $4 \mathrm{~h}$. The results of each condition show that hydrogen and oxygen meet the stoichiometric ratio of 2:1. As the $\mathrm{pH}$ value decreased from 2.4 to 1.9 , the amount of hydrogen produced increased, here resulting from the facilitation of more $\mathrm{H}^{+}$converting into hydrogen. However, although the $\mathrm{pH}$ was too low, $\mathrm{Fe}^{3+}$ tended to form $\left[\mathrm{Fe}\left(\mathrm{H}_{2} \mathrm{O}\right)_{6}\right]^{3+}$, which could not suppress the reverse reaction. ${ }^{37}$ Therefore, a lower $\mathrm{pH}$ value enhanced the hydrogen production rate and the reverse reaction rate, leading to an optimal $\mathrm{pH}$ value of 1.9.

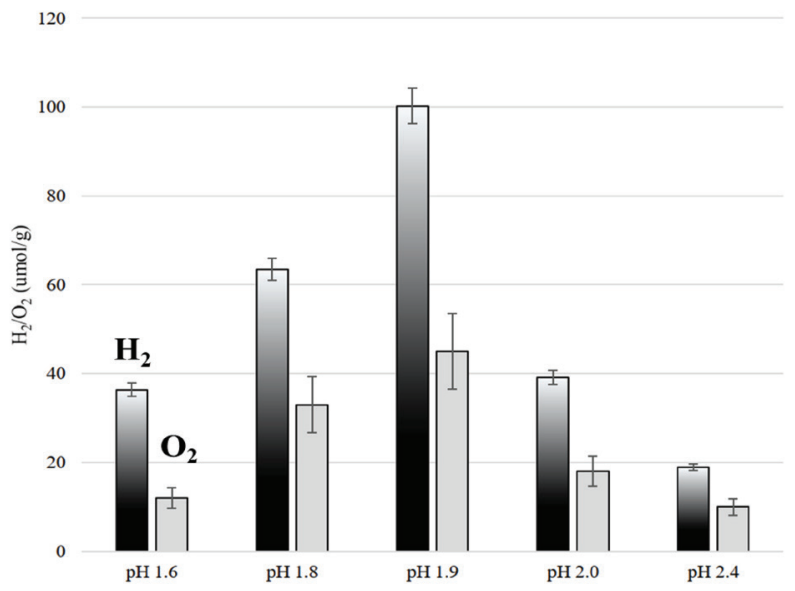

Figure 10: The effect of $\mathrm{pH}$ value on the hydrogen and oxygen production of the whole water-splitting reaction in a twin reactor using physically adsorbed N3$\mathrm{SrTiO}_{3}:$ Rh photocatalysts.

Subsequently, the dosage of the hydrogen-producing photocatalysts (physically adsorbed $\mathrm{N} 3-\mathrm{SrTiO}_{3}: \mathrm{Rh}$ ) was also tuned from $0.22 \mathrm{~g}$ to $0.10 \mathrm{~g}$ in a twin reactor, and the oxygen-producing photocatalysts $\left(\mathrm{WO}_{3}\right)$ was fixed at $0.22 \mathrm{~g}$. Similarly, the hydrogen and oxygen that was produced matched the stoichiometric ratio of 2:1. As shown in Figure 11, the maximum amount of hydrogen produced while using $0.14 \mathrm{~g}$ of physically adsorbed $\mathrm{N} 3-\mathrm{SrTiO}_{3}: \mathrm{Rh}$ photocatalysts was $180 \mu \mathrm{mol} / \mathrm{g}$ within $4 \mathrm{~h}$. When the dosage of the $\mathrm{N} 3-\mathrm{SrTiO}_{3}: \mathrm{Rh}$ photocatalysts decreased, the hydrogen production increased. These results occurred because of the shielding effect. Too many photocatalysts would block light absorption; therefore, each particle of the photocatalysts could not absorb the maximum light energy, leading to reduced photocatalytic performance. To sum up, the results show that optimal performance could be achieved when the $\mathrm{pH}$ of the solution was 1.9 and the amount of $\mathrm{N} 3-\mathrm{SrTiO}_{3}: \mathrm{Rh}$ photocatalysts was $0.14 \mathrm{~g}$. In addition, in the water-splitting reaction, the addition of $\mathrm{WO}_{3}$ was excessive because hydrogen production was the rate-determining step of the whole reaction. 


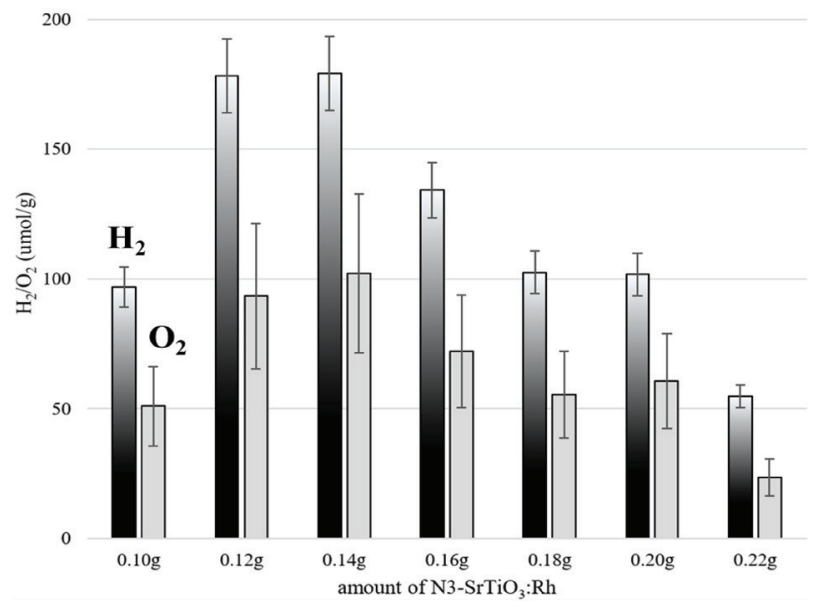

Figure 11: The effect of the dosage of physically adsorbed $\mathrm{N} 3-\mathrm{SrTiO}_{3}: \mathrm{Rh}$ photocatalysts on the hydrogen and oxygen production of the whole water-splitting reaction in a twin reactor.

The physically adsorbed $\mathrm{N} 3-\mathrm{SrTiO}_{3}: \mathrm{Rh}$ photocatalysts, however, were unstable because of the weak binding of physical adsorption between the N3 dye molecules and $\mathrm{SrTiO}_{3}: \mathrm{Rh}$ photocatalysts. Therefore, chemically bonded dyesensitised photocatalysts- $\mathrm{N} 3-\mathrm{SrTiO}_{3}: \mathrm{Rh}$ - were synthesised using APTES as the coupling agent. Figure 12 shows the comparison of hydrogen production over physically adsorbed $\mathrm{N} 3-\mathrm{SrTiO}_{3}: \mathrm{Rh}$ photocatalysts and chemically bonded N3$\mathrm{SrTiO}_{3}: \mathrm{Rh}$ photocatalysts in the half-reaction of water splitting. The $2 \mathrm{mM}$ of $\mathrm{Fe}^{2+}$ was added to $100 \mathrm{~mL}$ of deionised water, and the $\mathrm{pH}$ value was adjusted to 1.9. In the first round, physically adsorbed $\mathrm{N} 3-\mathrm{SrTiO}_{3}: \mathrm{Rh}$ photocatalysts exhibited higher hydrogen production than chemically bonded $\mathrm{N} 3-\mathrm{SrTiO}_{3}: \mathrm{Rh}$ photocatalysts. In comparison, no hydrogen was detected for the physically adsorbed $\mathrm{N}_{3}-\mathrm{SrTiO}_{3}: \mathrm{Rh}$ photocatalysts in the second round. On the other hand, in the first and second rounds, the chemically bonded $\mathrm{N} 3-\mathrm{SrTiO}_{3}: \mathrm{Rh}$ photocatalysts showed similar photocatalytic performance of hydrogen generation, the amount of which was

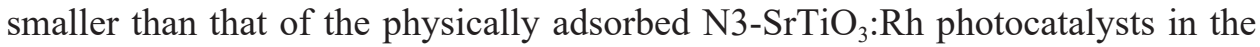
first round. Because of the silane coupling agent within the chemically bonded N3$\mathrm{SrTiO}_{3}: \mathrm{Rh}$ photocatalysts, it became difficult for the excited electrons to migrate across the coupling bridge, leading to a lower amount of hydrogen production in the first round. Nevertheless, the chemical bonding provided a stable structure to solve the issue that the $\mathrm{N} 3$ dye was easily desorbed and then resolved in water. Thus, chemically bonded $\mathrm{N} 3-\mathrm{SrTiO}_{3}: \mathrm{Rh}$ photocatalysts exhibited more secure structures than physically adsorbed $\mathrm{N} 3-\mathrm{SrTiO}_{3}: \mathrm{Rh}$ photocatalysts. 


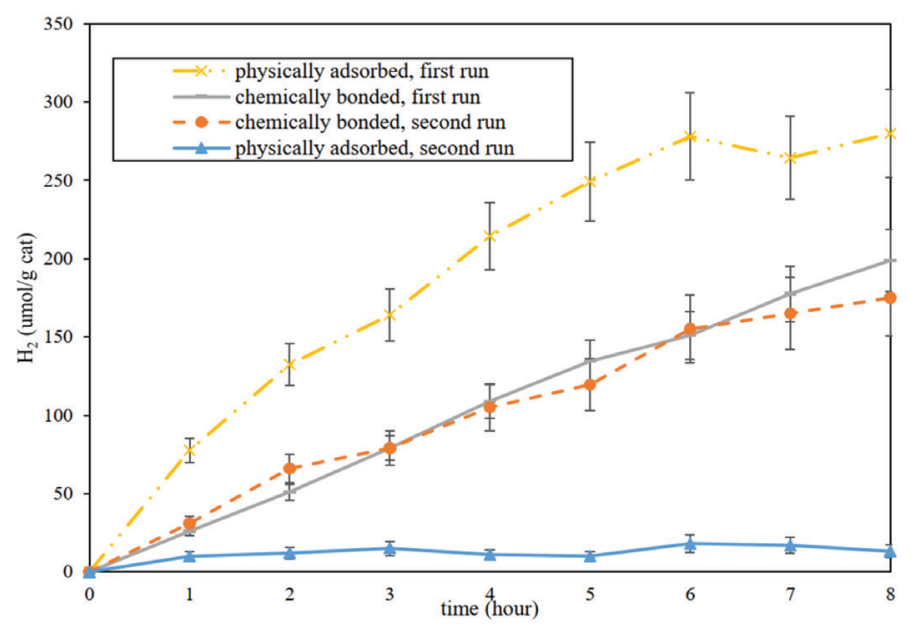

Figure 12: Hydrogen production over physically adsorbed $\mathrm{N}_{3}-\mathrm{SrTiO}_{3}: \mathrm{Rh}$ photocatalysts and chemically bonded $\mathrm{N} 3-\mathrm{SrTiO}_{3}: \mathrm{Rh}$ photocatalysts in the half-reaction of water splitting in a single reactor.

The whole water-splitting reaction was conducted in a twin reactor to examine hydrogen production over chemically bonded $\mathrm{N} 3-\mathrm{SrTiO}_{3}: \mathrm{Rh}$ photocatalysts. In the oxidation cell, $0.22 \mathrm{~g}$ of $\mathrm{WO}_{3}$ and $2 \mathrm{mM}$ of Fe ${ }^{3+}$ were added,

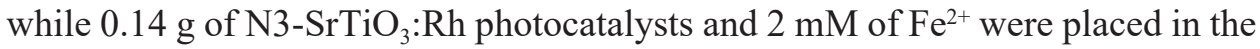
reduction cell. Both sides of the twin reactor were adjusted to have the $\mathrm{pH}$ value set at 1.9. Figure 13 shows that the amount of hydrogen produced by the physically adsorbed $\mathrm{N} 3-\mathrm{SrTiO}_{3}: \mathrm{Rh}$ photocatalysts was greater than that of the chemically bonded $\mathrm{N} 3-\mathrm{SrTiO}_{3}: \mathrm{Rh}$ photocatalysts. This chemical bonding using silane coupling agents as a bridge to synthesise the chemically bonded $\mathrm{N}_{3}-\mathrm{SrTiO}_{3}: \mathrm{Rh}$ photocatalysts made it challenging to transfer electrons in the first $4 \mathrm{~h}$. After $5 \mathrm{~h}$, the physically adsorbed $\mathrm{N} 3-\mathrm{SrTiO}_{3}: \mathrm{Rh}$ lost its photocatalytic ability because of the desorption of $\mathrm{N} 3$ dyes from the matrix of the photocatalysts. Therefore, the colour of the solution for the physically adsorbed $\mathrm{N}_{3}-\mathrm{SrTiO}_{3}: \mathrm{Rh}$ was obviously darkened. The desorbed N3 dyes were dissolved into water, resulting in the inability to generate hydrogen stably.

In contrast, the chemically bonded $\mathrm{N} 3-\mathrm{SrTiO}_{3}: \mathrm{Rh}$ photocatalysts could conduct the photocatalytic water-splitting reaction stably. The amount of hydrogen product over chemically bonded $\mathrm{N} 3-\mathrm{SrTiO}_{3}: \mathrm{Rh}$ photocatalysts for the whole water splitting in a twin reactor after $8 \mathrm{~h}$ of light irradiation could reach approximately $250 \mu \mathrm{mol} / \mathrm{g}$, which was not only greater than that of physically adsorbed N3$\mathrm{SrTiO}_{3}: \mathrm{Rh}$, but also than that in a single reactor. The results demonstrate that the chemically bonded $\mathrm{N} 3-\mathrm{SrTiO}_{3}: \mathrm{Rh}$ photocatalysts were stable. Cooperation with 
a twin reactor could avoid the reverse reaction, leading to a higher performance of hydrogen production and reduction of the cost of subsequent $\mathrm{H}_{2} / \mathrm{O}_{2}$ separation. Moreover, for the whole reaction, the photo-quantum efficiency of the chemically bonded $\mathrm{N} 3-\mathrm{SrTiO}_{3}: \mathrm{Rh}$ photocatalysts in a twin reactor system reached $0.026 \%$, which was approximately five times higher than that in a single reactor of $0.0052 \%$.

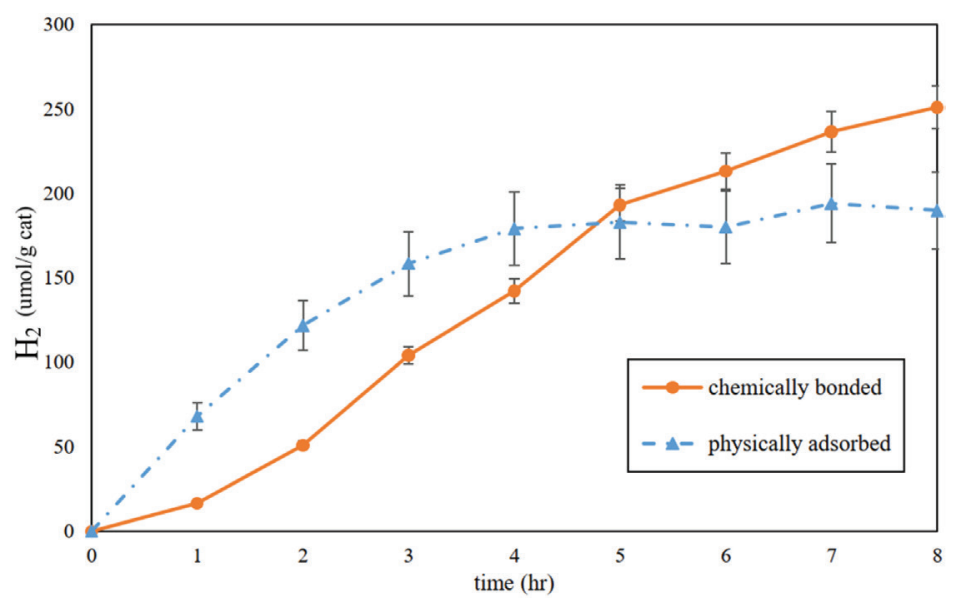

Figure 13: Hydrogen production over physically adsorbed $\mathrm{N} 3-\mathrm{SrTiO}_{3}: \mathrm{Rh}_{\text {photocatalysts }}$ and chemically bonded $\mathrm{N} 3-\mathrm{SrTiO}_{3}: \mathrm{Rh}$ photocatalysts for the whole reaction of water splitting in a twin reactor.

To quantify the amount of N3 dye that remained on the photocatalysts, $0.1 \mathrm{M} \mathrm{NaOH}$ was adopted to wash the fresh and spent photocatalysts. The detergent was detected by UV-Vis to confirm the amount of N3 dye molecules. Compared with the fresh photocatalysts, the chemically bonded photocatalysts adsorbed $79.42 \%$ of the N3 dye, while the physically adsorbed photocatalyst only adsorbed $50.28 \%$, as shown in Table 2. Because of the treatment of UV Ozone, the surface of the chemically bonded $\mathrm{N}_{3}-\mathrm{SrTiO}_{3}: \mathrm{Rh}$ photocatalysts formed numerous of hydrophilic hydroxyl groups, which could increase the number of the bonding of the functional groups, leading to more $\mathrm{N} 3$ dye molecules being grasped. After $8 \mathrm{~h}$ of water-splitting reaction, only about $30 \%$ of the dye remained on the surface of the physically adsorbed $\mathrm{N} 3-\mathrm{SrTiO}_{3}: \mathrm{Rh}$ photocatalysts, while the chemically bonded $\mathrm{N} 3-\mathrm{SrTiO}_{3}: \mathrm{Rh}$ photocatalysts lost a negligible amount of the $\mathrm{N} 3$ dyes, proving the stability of the chemically bonded $\mathrm{N} 3-\mathrm{SrTiO}_{3}: \mathrm{Rh}$ photocatalysts. 
Table 2: N3 adsorption of fresh and spent physically adsorbed and chemically bonded $\mathrm{N} 3-\mathrm{SrTiO}_{3}: \mathrm{Rh}$ photocatalysts.

\begin{tabular}{ccc}
\hline $\mathrm{N}_{-}-\mathrm{SrTiO}_{3}:$ Rh Photocatalysts & $\mathrm{N} 3$ adsorption (\%) \\
\hline \multirow{2}{*}{ Physically adsorbed } & Fresh & 50.28 \\
& Spent & 29.79 \\
Chemically bonded & Fresh & 79.42 \\
& Spent & 79.30 \\
\hline
\end{tabular}

The Fourier Transform Infrared (FTIR) analysis of the fresh and spent chemically bonded $\mathrm{N} 3-\mathrm{SrTiO}_{3}: \mathrm{Rh}$ photocatalysts is shown in Figure 14. Comparing the spectrum of pure N3 dyes, the chemically bonded N3$\mathrm{SrTiO}_{3}: \mathrm{Rh}$ photocatalysts exhibited a similar spectrum because of the existence of $\mathrm{N} 3$ dyes on the $\mathrm{SrTiO}_{3}: \mathrm{Rh}$ photocatalysts. The main peaks of the functional groups include $\mathrm{SCN}^{-}\left(2100 \sim 2150 \mathrm{~cm}^{-1}\right), \mathrm{C}-\mathrm{O}\left(1150 \sim 1250 \mathrm{~cm}^{-1}\right)$, and COO-(1350 $\sim 1450 \mathrm{~cm}^{-1}$ ), indicating the presence of N3 dyes. Despite conducting the watersplitting reaction, the spent photocatalysts remained at a similar FTIR spectrum as that of the fresh photocatalysts, suggesting that the chemically bonded $\mathrm{N} 3-\mathrm{SrTiO}_{3}: \mathrm{Rh}$ photocatalysts had stable structures for a long-term water-splitting reaction.

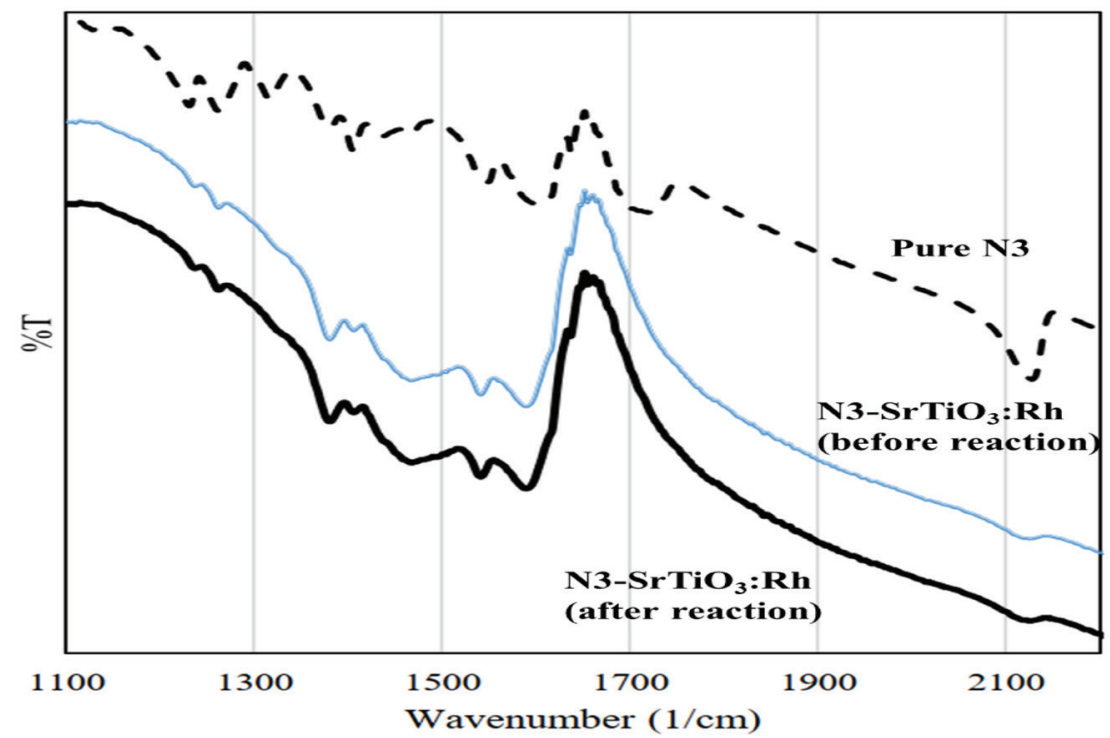

Figure 14: FTIR analysis of the fresh and spent chemically bonded $\mathrm{N} 3-\mathrm{SrTiO}_{3}: \mathrm{Rh}$ photocatalysts. 


\section{CONCLUSION}

In the present study, $\mathrm{SrTiO}_{3}: \mathrm{Rh}$ was prepared using a solid-state method at high temperatures. After the optimisation of the synthesising condition, $\mathrm{SrTiO}_{3}: \mathrm{Rh}$ photocatalysts prepared at $1100^{\circ} \mathrm{C}$ were adopted for dye sensitisation because of their good crystallinity, specific surface area, and light absorption ability. After adsorbing various dyes, the dye-sensitised $\mathrm{SrTiO}_{3}: \mathrm{Rh}$ photocatalysts exhibited a much higher photocatalytic hydrogen production than pure $\mathrm{SrTiO}_{3}: \mathrm{Rh}$ photocatalysts under radiation by a $300 \mathrm{~W}$ Xe lamp. Among these dye-sensitised $\mathrm{SrTiO}_{3}:$ Rh photocatalysts, $\mathrm{N} 3-\mathrm{TiO}_{3}: \mathrm{Rh}$ photocatalysts showed the best performance in producing hydrogen by $\sim 130 \mu \mathrm{mol} / \mathrm{g}$ in the half-reaction of water splitting in $8 \mathrm{~h}$, $\sim 15 \mu \mathrm{mol} / \mathrm{g}$ in the whole reaction system in a single reactor in $4 \mathrm{~h}$, and $\sim 19 \mu \mathrm{mol} / \mathrm{g}$ in the whole reaction system in a twin reactor in $4 \mathrm{~h}$. Therefore, the physically adsorbed and chemically bonded $\mathrm{N}_{3}-\mathrm{SrTiO}_{3}: \mathrm{Rh}$ photocatalysts were fabricated to verify their stability and photocatalytic performance. In the experiment in a single reactor, the physically adsorbed dye-sensitised photocatalysts had higher hydrogen production in the first round of reaction. However, because of the desorption and dissolution of the N3 dyes, the hydrogen production in the second round decreased, and almost no hydrogen was generated again. On the contrary, the chemically bonded photocatalysts maintained similar hydrogen production in the first and second rounds, showing the structural stability of the photocatalysts. By mimicking the Z-scheme system in the twin reactor, chemically bonded N3$\mathrm{SrTiO}_{3}: \mathrm{Rh}$ photocatalysts could reach the highest photocatalytic performance under the condition of a solution with a $\mathrm{pH}$ value of 1.9 and a photocatalysts dosage of $0.14 \mathrm{~g}$. Based on this system, hydrogen and oxygen could be generated at different cells, the reverse reaction could be avoided, and the light-shielding effect between the two photocatalysts could be ignored. In summary, the chemically bonded N3$\mathrm{SrTiO}_{3}: \mathrm{Rh}$ photocatalysts were synthesised successfully with stable chemical bonding between $\mathrm{N} 3$ dye molecules and $\mathrm{SrTiO}_{3}: \mathrm{Rh}$ photocatalysts through silane coupling agents. After optimisation, the twin reactor system incorporating chemically bonded $\mathrm{N} 3-\mathrm{SrTiO}_{3}: \mathrm{Rh}$ photocatalysts reached the highest photoquantum efficiency of up to $0.026 \%$.

\section{ACKNOWLEDGEMENT}

The authors gratefully acknowledge the NTU-ITRI Nano Material collaboration, project no. 07HZE1100I and the Ministry of Science and Technology, Taiwan, MOST 105-2221-E-002-206-MY3, for the financial support. Special thanks to Dr. Sheng-Min Yu of ITRI for experimental assistance. 


\section{REFERENCES}

1. Dicks, A. L., Pointon, K. D. \& Siddle, A. (2000). Intrinsic reaction kinetics of methane steam reforming on a nickel/zirconia anode. J. Power Sources, 86, 523-530, https://doi.org/10.1016/S0378-7753(99)00447-4.

2. Herring, J. S., O’Brien, J. E., Stoots, C. M., Hawkes, G. L., Hartvigsen, J. J. \& Shahnam, M. (2007). Progress in high-temperature electrolysis for hydrogen production using planar SOFC technology. Int. J. Hydrog. Energy, 32(4), 440-450, https://doi.org/10.1016/j.ijhydene.2006.06.061.

3. Laosiripojana, N. \& Assabumrungrat, S. (2007). Catalytic steam reforming of methane, methanol, and ethanol over Ni/YSZ: The possible use of these fuels in internal reforming SOFC. J. Power Sources, 163(2), 943-951, https://doi.org/10.1016/j.jpowsour.2006.10.006.

4. Fujishima, A. \& Honda, K. (1972). Electrochemical photolysis of water at a semiconductor electrode. Nature, 238, 37-38, https://doi. org/10.1038/238037a0.

5. Jafari, T., Moharreri, E., Amin, A. S., Miao, R., Song, W. \& Suib, S. L. (2016). Photocatalytic water splitting: The untamed dream: A review. Molecules, 21(7), 900, https://doi.org/10.3390/molecules21070900.

6. Huang, C. W., Nguyen, B. S., Wu, J. C. S. \& Nguyen, V. H. (2020). A current perspective for photocatalysis towards the hydrogen production from biomass-derived organic substances and water. Int. J. Hydrogen Energy, 45(36), 18144-18159, https://doi.org/10.1016/j.ijhydene.2019.08.121.

7. Huang, C. W., Nguyen, V. H., Zhou, S. R., Hsu, S. Y., Tan, J. X. \& Wu, K. C. W. (2020). Metal-organic frameworks: Preparation and applications in highly efficient heterogeneous photocatalysis. Sustain. Energy Fuels, 4(2), 504-521, https://doi.org/10.1039/C9SE00972H.

8. Liao, C. H., Huang, C. W. \& Wu, J. (2012). Hydrogen production from semiconductor-based photocatalysis via water splitting. Catalysts, 2(4), 490-516, https://doi.org/10.3390/catal2040490.

9. Chen, H. C., Huang, C. W., Wu, J. C. \& Lin, S. T. (2012). Theoretical investigation of the metal-doped $\mathrm{SrTiO} 3$ photocatalysts for water splitting. J. Phys. Chem. C., 116(14), 7897-7903, https://doi.org/10.1021/ jp300910e.

10. Dholam, R., Patel, N., Adami, M. \& Miotello, A. (2009). Hydrogen production by photocatalytic water-splitting using $\mathrm{Cr}$-or Fe-doped TiO2 composite thin films photocatalyst. Int. J. Hydrogen Energy, 34(13), 5337-5346, https://doi.org/10.1016/j.ijhydene.2009.05.011. 
11. Maeda, K. \& Domen, K. (2010). Photocatalytic water splitting: Recent progress and future challenges. J. Phys. Chem. Lett., 1(18), 2655-2661, https://doi.org/10.1021/jz1007966.

12. Iwase, A., Kato, H. \& Kudo, A. (2005). A novel photodeposition method in the presence of nitrate ions for loading of an iridium oxide cocatalyst for water splitting. Chem. Lett., 34(7), 946-947, https:/doi.org/10.1246/ cl.2005.946.

13. Lo, C. C., Huang, C. W., Liao, C. H. \& Wu, J. C. (2010). Novel twin reactor for separate evolution of hydrogen and oxygen in photocatalytic water splitting. Int. J. Hydrogen Energy, 35(4), 1523-1529, https://doi. org/10.1016/j.ijhydene.2009.12.032.

14. Watanabe, M. (2017). Dye-sensitised photocatalyst for effective water splitting catalyst. Sci. Technol. Adv. Mater., 18, 705-723, https://doi.org/1 0.1080/14686996.2017.1375376.

15. Kiwi, J. \& Grätzel, M. (1979). Hydrogen evolution from water induced by visible light mediated by redox catalysis. Nature, 281, 657-658, https:// doi.org/10.1038/281657a0.

16. Maeda, K., Sahara, G., Eguchi, M. \& Ishitani, O. (2015). Hybrids of a ruthenium(II) Polypyridyl complex and a metal oxide nanosheet for dyesensitized hydrogen evolution with visible light: Effects of the energy structure on photocatalytic activity. ACS Catal., 5(3), 1700-1707, https:// doi.org/10.1021/acscatal.5b00040.

17. Yu, F., Wang, Z., Zhang, S., Yun, K., Ye, H., Gong, X., Hua, J. \& Tian, H. (2018). N-Annulated perylene-based organic dyes sensitized graphitic carbon nitride to form an amide bond for efficient photocatalytic hydrogen production under visible-light irradiation. Appl. Catal. B., 237, 32-42, https://doi.org/10.1016/j.apcatb.2018.05.045.

18. Wang, P., Guan, Z., Li, Q. \& Yang, J. (2018). Efficient visible-lightdriven photocatalytic hydrogen production from water by using Eosin Y-sensitized novel gC 3 N 4/Pt/GO composites. J. Mater. Sci., 53, 774786, https://doi.org/10.1007/s10853-017-1540-5.

19. Qin, J., Huo, J., Zhang, P., Zeng, J., Wang, T. \& Zeng, H. (2016). Improving the photocatalytic hydrogen production of $\mathrm{Ag} / \mathrm{gC} 3 \mathrm{~N} 4$ nanocomposites by dye-sensitization under visible light irradiation. Nanoscale, 8, 22492259, https://doi.org/10.1039/C5NR06346A.

20. Wang, Y., Hong, J., Zhang, W. \& Xu, R. (2013). Carbon nitride nanosheets for photocatalytic hydrogen evolution: Remarkably enhanced activity by dye sensitization. Catal. Sci. Technol., 3(7), 1703-1711, https://doi. org/10.1039/c3cy20836b. 
21. Zhang, X., Veikko, U., Mao, J., Cai, P. \& Peng, T. (2012). Visible-lightinduced photocatalytic hydrogen production over binuclear RuII-bipyridyl dye-sensitised $\mathrm{TiO} 2$ without noble metal loading. Chem. Eur. J., 18(38), 12103-12111, https://doi.org/10.1002/chem.201200725.

22. Li, J., Yue, E., Lian, L. \& Ma, W. (2013). Visible light induced dyesensitized photocatalytic hydrogen production over platinized $\mathrm{TiO} 2$ derived from decomposition of platinum complex precursor. Int. J. Hydrogen Energy, 38(25), 10746-10753, https://doi.org/10.1016/j. ijhydene.2013.02.121.

23. Maia, D. L. S., Pepe, I., da Silva, A. F. \& Silva, L. A. (2012). Visible-lightdriven photocatalytic hydrogen production over dye-sensitized $\beta$-BiTaO4. J. Photochem. Photobiol. A., 243, 61-64, https://doi.org/10.1016/j. jphotochem.2012.06.008.

24. He, J., Wang, J., Chen, Y., Zhang, J., Duan, D., Wang, Y. \& Yan, Z. (2014). A dye-sensitized Pt@ UiO-66 (Zr) metal-organic framework for visible-light photocatalytic hydrogen production. Chem. Commun., 50(53), 7063-7066, https://doi.org/10.1039/C4CC01086H.

25. Yuan, Y. P., Yin, L. S., Cao, S. W., Xu, G. S., Li, C. H. \& Xue, C. (2015). Improving photocatalytic hydrogen production of metal-organic framework UiO-66 octahedrons by dye-sensitisation. Appl. Catal. B., 168, 572-576, https://doi.org/10.1016/j.apcatb.2014.11.007.

26. Jia, T., Li, M. M., Ye, L., Wiseman, S., Liu, G., Qu, J., Nakagawa, K. \& Tsang, S. E. (2015). The remarkable activity and stability of a dyesensitized single molecular layer MoS 2 ensemble for photocatalytic hydrogen production. Chem. Commun., 51(70), 13496-13499, https://doi. org/10.1039/C5CC03871E.

27. Puangpetch, T., Sommakettarin, P., Chavadej, S. \& Sreethawong, T. (2010). Hydrogen production from water splitting over Eosin Y-sensitized mesoporous-assembled perovskite titanate nanocrystal photocatalysts under visible light irradiation. Int. J. Hydrogen Energy, 35(22), 1242812442, https://doi.org/10.1016/j.ijhydene.2010.08.138.

28. Maeda, K. (2014). Rhodium-doped barium titanate perovskite as a stable p-type semiconductor photocatalyst for hydrogen evolution under visible light. ACS Appl. Mater. Interfaces, 6(3), 2167-2173, https://doi. org/10.1021/am405293e.

29. Kato, H., Asakura, K. \& Kudo, A. (2003). Highly efficient water splitting into $\mathrm{H} 2$ and $\mathrm{O} 2$ over lanthanum-doped $\mathrm{NaTaO} 3$ photocatalysts with high crystallinity and surface nanostructure. J. Am. Chem. Soc., 125(10), 30823089, https://doi.org/10.1021/ja027751g. 
30. Mao, M., Xu, J., Li, L., Zhao, S., Li, X., Li, Y. \& Liu, Z. (2019). High performance hydrogen production of MoS 2-modified perovskite LaNiO 3 under visible light. Ionics, 25, 4533-4546, https://doi.org/10.1007/ s11581-019-03210-2.

31. Kato, H., Hori, M., Konta, R., Shimodaira, Y. \& Kudo, A. (2004). Construction of Z-scheme type heterogeneous photocatalysis systems for water splitting into $\mathrm{H} 2$ and $\mathrm{O} 2$ under visible light irradiation. Chem. Lett., 33(10), 1348-1349, https://doi.org/10.1246/cl.2004.1348.

32. Li, D., Yu, J. C. C., Nguyen, V. H., Wu, J. C. \& Wang, X. (2018). A dual-function photocatalytic system for simultaneous separating hydrogen from water splitting and photocatalytic degradation of phenol in a twin-reactor. Appl. Catal. B., 239, 268-279, https://doi.org/10.1016/j. apcatb.2018.08.010.

33. Abe, R., Hara, K., Sayama, K., Domen, K. \& Arakawa, H. (2000). Steady hydrogen evolution from water on Eosin $\mathrm{Y}$-fixed $\mathrm{TiO} 2$ photocatalyst using a silane-coupling reagent under visible light irradiation. J. Photochem. Photobiol. A., 137, 63-69, https://doi.org/10.1016/S1010-6030(00)003518.

34. Yu, S. C., Huang, C. W., Liao, C. H., Wu, J. C., Chang, S. T. \& Chen, K. H. (2011). A novel membrane reactor for separating hydrogen and oxygen in photocatalytic water splitting. J. Membr. Sci., 382, 291-299, https://doi. org/10.1016/j.memsci.2011.08.022.

35. Lin, H. Y. \& Cian, L. T. (2019). Microwave-assisted hydrothermal synthesis of SrTiO3: Rh for photocatalytic Z-scheme overall water splitting. Appl. Sci., 9, 55, https://doi.org/10.3390/app9010055.

36. Chen, D. \& Ye, J. (2007). SrSnO3 nanostructures: Synthesis, characterization, and photocatalytic properties. Chem. Mater., 19(18), 4585-4591, https://doi.org/10.1021/cm071321d.

37. Kato, H., Sasaki, Y., Iwase, A. \& Kudo, A. (2007). Role of iron ion electron mediator on photocatalytic overall water splitting under visible light irradiation using Z-scheme systems. Bull. Chem. Soc. Jpn., 80(12), 2457-2464, https://doi.org/10.1246/bcsj.80.2457. 